\title{
FORKLIFT TRUCK SELECTION USING TOPSIS METHOD
}

\author{
Petr Průša ${ }^{1}$, Stefan Jovčić ${ }^{2}$, Vladimír Němec ${ }^{3}$, Petr Mrázek ${ }^{4}$ \\ 1,2,3,4 University of Pardubice, The Faculty of Transport Engineering, Studentská 95, 53210 Pardubice, Czech Republic
}

Received 1 April 2018; accepted 30 June 2018

\begin{abstract}
Forklift trucks have a very important role in manipulating goods in the logistics industry and, therefore, companies must pay special attention to them. There are different types of forklifts and when make a decision, companies select some of the important criterias on the basis of which different forklift trucks will be chosen. The subject of research paper is the selection of a forklift truck for manipulating goods in the warehouse. A TOPSIS method was used to select the forklift truck, a well-known method of multi-criteria analysis, which has been proven in practice as a very efficient and reliable when deciding. The main result of this paper is determining the best alternative that would be the optimal solution for the logistics company. The decision was made on the basis of observation of four forklift trucks with five characteristics of different sizes.
\end{abstract}

Keywords: TOPSIS method, multi-criteria analysis, forklift, logistics, investment.

\section{Introduction}

In many branches of industry, especially in logistics, internal transport is a very important part of logistics processes, because it connects most of the segments, including relocation of goods within the premises of the logistics company. However, warehouse operations cannot be imagined without transport-manipulative units, so called forklift trucks whose features allows easy and simple handling of goods. Therefore, when investing in transport handling units, companies have to pay special attention when selecting the forklits, to use their characteristics in the best possible way and adapt to their needs in the warehouse in order to achieve profit. Forklifts are designed for the purposes of logistic centers. (Kampf et al., 2011) defined logistic center as a point designed for concentration of a wide variety of logistic services including combined transportation through at least two transport modes (road, railway, water).
Forklifts characterize features such as heavy loads lifting, easy maneuverability in small spaces, easy acceptance and disposal of goods and etc. (Sabadka et al., 2017) emphasized that the efficiency of the machine influences the overall productivity of production and should therefore be taken into account when determining it. When making a investing decision in transport manipulative units, a multicriteria analyses is used.

In recent years, there has been a strong development and unusual popularity of multi-criteria analysis methods. In practical terms, the methods of multicriteria analysis provide great assistance in solving everyday tasks, decisionmaking and management actions, tools in designing and methodological support in the exploitation of the most diverse system. Therefore, multicriteria analysis aims to compare different actions or solutions according to a variety of criteria and policies.

${ }^{1}$ Corresponding author: petr.prusa@upce.cz 
The main objective of this paper is selection of forklift unit for the purposes of warehouse operations in logistics company. To solve these kind of decision making problems, the TOPSIS method was used, because that method has been proven as a very useful in solving these kind of problems.

Before a specific problem is shown, examples of using the TOPSIS method are given below. (Chen et al., 2006) used fuzzy TOPSIS systematic approach for solving problem based on profitability of a supplier. For the location problem, TOPSIS approach was presented in to select plant locations, where for each criterion the ratings of various locations were assessed (Yong, 2006). Also, the robot selection process was proposed by the same method (Shih, 2008). Fuzzy TOPSIS model was used for the selection of the most suitable logistics service provider (Bottani \& Rizzi, 2006). In combination with simulation and fuzzy TOPSIS, method was conducted for evaluation of four service providers (Chamodrakas et al., 2011). Also, facility size selection problem is given (Chu \& Lin, 2009).
The following part of the paper is organised as follows: the second section describes general state of TOPSIS method. Description of situation of logistics company and application of method on particular example was given in sections three and four respectively. The conclusion of this paper is given in section five.

\section{TOPSIS Method}

The Technique for Order of Preference by Similarity to Ideal Solution (TOPSIS) is a multi-criteria decision analysis method, which was originally developed by (Hwang and Yoon, 1981) with further developments by (Yoon, 1987) and (Hwang et al., 1993). Alternatives of TOPSIS methods are evaluated based on their distance in relation to the ideal and anti-ideal solution. The alternative is considered best if there is a minimum distance in relation to the ideal solution and the greatest distance from the anti-ideal solution. The next figure (Figure 1) is a spatial distribution of alternatives defined by two criteria of the max type. With $\mathrm{A}+$ and A- respectively, ideal and anti-ideal solutions are marked.

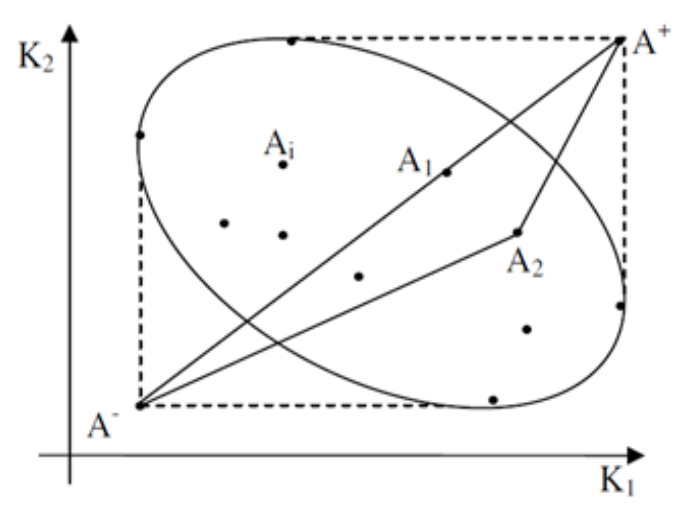

Fig.1.

Alternative Distance from Ideal and Anti-Ideal Solution

Source: (Dimitrijević, 2017) 
The general setting of the multi-criteria decision problem is given below (Table 1).

\section{Table 1}

General Setting of Multicriteria Problem

\begin{tabular}{|c|c|c|c|c|c|c|c|}
\hline & & \multicolumn{6}{|c|}{ Criteria } \\
\hline & & K1 & K2 & $\ldots$ & $\mathbf{K j}$ & ... & Kn \\
\hline \multirow{8}{*}{ 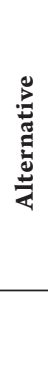 } & A1 & $\mathrm{X} 11$ & $\mathrm{X} 12$ & $\ldots$ & $\mathrm{X} 1 \mathrm{j}$ & $\ldots$ & $\mathrm{X} 1 \mathrm{n}$ \\
\hline & A2 & $\mathrm{X} 21$ & X22 & $\ldots$ & $\mathrm{X} 2 \mathrm{j}$ & $\ldots$ & $\mathrm{X} 2 \mathrm{n}$ \\
\hline & $\vdots$ & $\cdots$ & $\ldots$ & $\ldots$ & $\cdots$ & $\ldots$ & $\ldots$ \\
\hline & $\mathbf{A i}$ & Xi1 & $\mathrm{Xi2}$ & $\ldots$ & $\mathrm{Xij}$ & $\ldots$ & Xin \\
\hline & $\vdots$ & $\vdots$ & $\vdots$ & $\ldots$ & $\vdots$ & $\ldots$ & ... \\
\hline & Am & $\mathrm{Xm} 1$ & $\mathrm{Xm} 2$ & $\ldots$ & $\mathrm{Xmj}$ & $\ldots$ & $\mathrm{Xmn}$ \\
\hline & $\max / \min$ & $\max$ & $\max$ & $\ldots$ & $\min$ & $\ldots$ & $\min$ \\
\hline & $\mathbf{W j}$ & W1 & W2 & $\ldots$ & $\mathrm{Wj}$ & $\ldots$ & Wn \\
\hline
\end{tabular}

Source:(Authors)

Symbols A1, A2,...Am are alternatives between which selects the best, while labels $\mathrm{K} 1, \mathrm{~K} 2, \ldots \mathrm{Kn}$ are the criteria by which the best alternative was selected. $\mathrm{Xij}$ represents the value of the $i$-th alternative according to the j-th criterion. Marks max / min indicate the type of criteria, that is, certain criteria should be maximized, while others should be minimized. W1 ... Wn denote the weight of the criteria, or their significance. The TOPSIS method can be described through several steps. The first step is data normalization, that is, the reduction of input data to an interval of values 0 to 1. The normalization is done based on the following formula (1):

$\mathrm{R}=r i j=\frac{x i j}{\sqrt{\sum_{i=1}^{n} x i j^{2}}}$

where is: R - normalized matrix, rij normalized data
The next step is the multiplication of normalized data with normalized weight of the criteria based on the following formula (2):

$V i j=W j^{\prime} \cdot r i j$

Whereby $W^{\prime}$ is obratined on the following way in formula (3):

$W j^{\prime}=\frac{W j}{\sum_{j=1}^{n} W j}$

On the basis of the obtained values from the previous step, the following step is the formulation of the above-mentioned ideal and anti-ideal solution ( $\mathrm{A}+$ and $\mathrm{A}-) . \mathrm{A}+$ represents the ideal solution which has all the best characteristics of all the criteria, and 
A- is an anti-ideal solution that has all the characteristics of the worst for all criteria. This is determined by the formula (4) and (5):

$A^{+}=\left\{\left(\max _{i} V i j, j \in K^{\prime}\right) \mid\left(\min _{i} V i j, j \in K^{\prime \prime}\right)\right\}=\{V 1+, V 2+, \ldots V j+, . . V n+\}$, $(i=1 \ldots m)$

$A-=\left\{\left(\min _{i} V i j, j \in K^{\prime}\right) \mid\left(\max _{i} V i j, j \in K^{\prime \prime}\right)\right\}=\{V 1-, V 2-, \ldots V j-, . . V n-\}$ $(i=1 \ldots m)$

$K^{\prime}$ represents a subset of the $\mathrm{K}$ set, which consists of criteria of max type and $K^{\prime \prime}$ represents a subset of the $\mathrm{K}$ set, which consists of criteria of min type.

In the next step, the euclidean distance (6) and (7) of each alternative from the ideal and anti-ideal solution is counted:

$$
\begin{aligned}
& S i+=\sqrt{\sum_{j=1}^{n}(V i j-V j+)^{2}} \\
& S i-=\sqrt{\sum_{j=1}^{n}(V i j-V j-)^{2}}
\end{aligned}
$$

$S i+$ represents the distance of the i-th alternative from an ideal solution

$S i$ - represents the distance of the i-th alternative from an anti-ideal solution

After this step, the relative closeness of the alternative to the ideal solution is calculated based on the formula (8):

$$
C i=\frac{S i-}{S i-+S i+}, \quad[0 \leq C i \leq 1]
$$

\section{Description of Situation}

Logistics company makes a decision about investing in the field of transport and manipulative units for purpose of warehouse. The management of logistics company has made short listed manufacturers of forklift trucks, so called alternatives, which names in this article, had not been emphasized from legal reasons. It is necessary to make a decision between four forklift trucks. The selection of forklift trucks is done on the basis of certain criteria defined by the management of company. According to that, following criteria are listed below:

- Capacity of lifting - is determined as the maximum weight that a forklift is able to safely carry at a specified load centre;

- Capacity of battery - it is very important to know because of time of operating for forklift trucks. The time for battery charge is very important as well;

- Lifting height - according to managers, this criteria is also very important for warehouse operations, because their warehouse use racks with levels and they need forklift truck with as high as possible lifting height capability;

- Travel speed with load - this criteria is taken into account because the speed is very important factor in order to reduce operative costs and accelerate load shifting operations;

- Price - As the last criterion included in the consideration of alternatives is price. When making a decision, the price plays a very important role. Of course, the goal of the company is to perform with a smaller investment in selecting transport manipulative units that will later profit.

Therefore, based on the defined criteria, a forklift truck with the best characteristics 
is selected, which currently corresponds to meeting the needs of the logistics company. In the next part of the article, one of the methods of multi-criteria decision making, so-called TOPSIS method, was used to make the best decision. The author's decision to use this method was made on the basis of the experience that the TOPSIS method is proven as a very effective tool in practice for solving these kinds of problems.

\section{Forklift Truck Selection}

Initially, the problem is accessed in such a way that the matrix of the comparison of alternatives is formed based on the set criteria. Some of the criteria is necessary to be maximized, while some others is necessary to be minimized. This is shown in Table 2.

Table 2

The Matrix of the Comparison of Alternatives by the Criteria

\begin{tabular}{|c|c|c|c|c|c|}
\hline $\begin{array}{c}\text { Criteria } \\
\text { Alternatives }\end{array}$ & $\begin{array}{c}\text { Capacity of } \\
\text { lifting }[\mathbf{k g}]\end{array}$ & $\begin{array}{c}\text { Capacity of } \\
\text { battery }[\mathbf{h}]\end{array}$ & $\begin{array}{c}\text { Lifting height } \\
{[\mathbf{m}]}\end{array}$ & $\begin{array}{c}\text { Travel speed } \\
\text { with load m/s] }\end{array}$ & $\begin{array}{c}\text { Price } \\
{[\text { Euro] }}\end{array}$ \\
\hline Forklift 1 & 1300 & 5 & 3.3 & 4.91 & 14.000 \\
\hline Forklift 2 & 2500 & 4 & 4.5 & 4.44 & 14.200 \\
\hline Forklift 3 & 2000 & 5 & 2.8 & 4.44 & 13.600 \\
\hline Forklift 4 & 1800 & 6 & 5.4 & 4.91 & 15.800 \\
\hline $\mathbf{m a x} / \mathbf{m i n}$ & $\max$ & $\max$ & $\max$ & $\max$ & min \\
\hline
\end{tabular}

Source: (Autors)

As can be seen in the table, it is in the interest of the company that the forklift truck has a bigger load capacity, battery capacity, lift height and higher speeds when the loads is being transported, while all this can be obtained for as low a price as possible. Of all these characteristics, the management of the company devotes special attention to the forklift truck with a higher load capacity, as well as the lift height, while the battery capacity, the speed with the load and the prices can be treated as criteria with a somewhat minor importance. Based on this, by the agreement of the author of this paper, the assessment of the criteria based on the Saaty's scale.
This is the scale of the criteria evaluation. They function in such a way that the criteria are compared to each other according to the pairs, and the matrix of domination of one against the other criterion is formed.

After comparing the pairs of alternatives and entering the appropriate estimates, the sums of total domination for each of the criteria are formed and then normalized. By summing the normalized data by type, the weight of the criteria is obtained. The next table presents comparison matrix with criteria weights. 
Table 3

Comparison Matrix with Criteria Weights

\begin{tabular}{|c|c|c|c|c|c|}
\hline $\begin{array}{c}\text { Criteria } \\
\text { Alternatives }\end{array}$ & $\begin{array}{c}\text { Capacity of } \\
\text { lifting }[\mathbf{k g}]\end{array}$ & $\begin{array}{c}\text { Capacity of } \\
\text { battery }[\mathbf{h}]\end{array}$ & $\begin{array}{c}\text { Lifting height } \\
{[\mathbf{m}]}\end{array}$ & $\begin{array}{c}\text { Travel speed } \\
\text { with load [m/s] }\end{array}$ & $\begin{array}{c}\text { Price } \\
{[\text { Euro] }}\end{array}$ \\
\hline Forklift 1 & 1300 & 5 & 3.3 & 4.91 & 14.000 \\
\hline Forklift 2 & 2500 & 4 & 4.5 & 4.44 & 14.200 \\
\hline Forklift 3 & 2000 & 5 & 2.8 & 4.44 & 13.600 \\
\hline Forklift 4 & 1800 & 6 & 5.4 & 4.91 & 15.800 \\
\hline max/min & $\max$ & $\max$ & $\max$ & $\max$ & min \\
\hline Weights $(\mathbf{W j})$ & 1.605 & 0.789 & 1.080 & 0.305 & 1.222 \\
\hline
\end{tabular}

Source: (Autors)

After the matrix of the comparison of data normalization is started. Using the alternatives according to the criteria formula (1), the normalized data given in with all the necessary data is obtained, the following table is obtained.

\section{Table 4}

Normalisation of Data

\begin{tabular}{|c|c|c|c|c|c|}
\hline $\begin{array}{c}\text { Criteria } \\
\text { Alternatives }\end{array}$ & $\begin{array}{l}\text { Capacity of } \\
\text { lifting }[\mathbf{k g}]\end{array}$ & $\begin{array}{l}\text { Capacity of } \\
\text { battery }[\mathbf{h}]\end{array}$ & Lifting height $[\mathrm{m}]$ & $\begin{array}{c}\text { Travel speed } \\
\text { with load } \\
{[\mathrm{m} / \mathrm{s}]} \\
\end{array}$ & $\begin{array}{l}\text { Price } \\
\text { [Euro] }\end{array}$ \\
\hline Forklift 1 & 0.334 & 0.495 & 0.400 & 0.524 & 0.485 \\
\hline Forklift 2 & 0.642 & 0.396 & 0.545 & 0.474 & 0.492 \\
\hline Forklift 3 & 0.513 & 0.495 & 0.339 & 0.474 & 0.471 \\
\hline Forklift 4 & 0.462 & 0.594 & 0.654 & 0.524 & 0.548 \\
\hline $\begin{array}{c}\text { Weights } \\
(\mathbf{W j})\end{array}$ & 0.321 & \multicolumn{2}{|c|}{0.158} & 0.061 & 0.244 \\
\hline
\end{tabular}

Source: (Autors)

Based on formulas (2) and (3), a difficult decision matrix is obtained and this is shown in Table 5.

\section{Table 5}

Weighted Decision Making Matrix

\begin{tabular}{|c|c|c|c|c|c|}
\hline $\begin{array}{c}\text { Criteria } \\
\text { Alternatives }\end{array}$ & $\begin{array}{l}\text { Capacity of } \\
\text { lifting }[\mathbf{k g}]\end{array}$ & $\begin{array}{l}\text { Capacity of } \\
\text { battery }[\mathbf{h}]\end{array}$ & Lifting height $[\mathrm{m}]$ & $\begin{array}{c}\text { Travel speed with } \\
\text { load }[\mathrm{m} / \mathrm{s}]\end{array}$ & $\begin{array}{l}\text { Price } \\
\text { [Euro] }\end{array}$ \\
\hline Forklift 1 & 0.107 & 0.078 & 0.086 & 0.032 & 0.119 \\
\hline Forklift 2 & 0.206 & 0.062 & 0.118 & 0.029 & 0.120 \\
\hline Forklift 3 & 0.165 & 0.078 & 0.073 & 0.029 & 0.115 \\
\hline Forklift 4 & 0.148 & 0.094 & 0.141 & 0.032 & 0.134 \\
\hline $\begin{array}{l}\text { Weights } \\
(\mathbf{W j})\end{array}$ & 0.321 & 0.158 & 0.216 & 0.061 & 0.244 \\
\hline $\max / \min$ & $\max$ & $\max$ & $\max$ & $\max$ & $\min$ \\
\hline
\end{tabular}

Source: (Autors) 
From the table 5, ideal and anti-ideal solution can be determined by all criteria, or maximum and minimum value, using formulas (4) and (5). The values obtained are given in table 6.

\section{Table 6}

\section{Ideal and Anti-Ideal Solution by Criteria}

\begin{tabular}{|c|c|}
\hline $\boldsymbol{V j}+$ & $\boldsymbol{V j}-$ \\
\hline 0.206 & 0.107 \\
\hline 0.094 & 0.062 \\
\hline 0.141 & 0.073 \\
\hline 0.032 & 0.029 \\
\hline 0.134 & 0.115 \\
\hline
\end{tabular}

Source: (Autors)

Now that ideal and anti-ideal solutions are determined, according to formulas (6) and (7), the next step is to determine the distance of the alternative to the ideal (S+), or antiideal (S-) solution. The values obtained are presented in Table 7.

Table 7

The Distance of Alternative from Ideal and Anti-Ideal Solution

\begin{tabular}{|c|c|}
\hline $\boldsymbol{S i}$ & $\boldsymbol{S i}$ \\
\hline 0.115 & 0.0209 \\
\hline 0.042 & 0.1058 \\
\hline 0.083 & 0.0597 \\
\hline 0.058 & 0.0875 \\
\hline
\end{tabular}

Source: (Autors)

We are interested in how much is each alternative close to ideal solution. This can be determined according to formula (8). Distances from the ideal solution are given in the table 8 bellow.

\section{Table 8}

The Distance of Each Alternative to Ideal Solution

\begin{tabular}{|c|c|}
\hline Alternative & Distance to ideal solution \\
\hline $\mathrm{C} 1$ & 0.1535 \\
\hline $\mathrm{C} 2$ & 0.7233 \\
\hline $\mathrm{C} 3$ & 0.4179 \\
\hline $\mathrm{C} 4$ & 0.5126 \\
\hline
\end{tabular}

Source: (Autors)

Now, when the obtained distance results are alternatives to the ideal solution, their ranking is done, from the best to the worst. In our case, from Table 8 it can be seen that the best alternative is $\mathrm{C} 2$, then $\mathrm{C} 4, \mathrm{C} 3$ and finally $\mathrm{C} 1$. Previously, it was noted in the text that the ranking alternative $\mathrm{Ci}$ corresponds to the ranking of the alternative Ai. 
In our case, it is best to choose alternative number two or forklift 2 with the following characteristics: capacity of lifting 2.500 [kg], capacity of battery $4[\mathrm{~h}]$, lifting height 4.5 $[\mathrm{m}]$, travel speed with load $4.44[\mathrm{~m} / \mathrm{s}]$ for price 14.200 [EUR]. The worst solution is the alternative number one, because the capacity of this forklift truck is very small, in comparison with the price, and the height of the lift is not too high. The fourth alternative can also be considered, and the difference in relation to the first is only in the price and capacity, which may not be decided by the management of the company, depending on the financial resources.

So, to summarize, the best solution for the company, given the criteria considered, obtained by the TOPSIS method is definitely a forklift truck 2. Depending on the financial resources, the company will make a decision on the purchase.

\section{Conclusion}

In this paper, the problem of selection a forklift truck for the needs of logistic company is solved by the TOPSIS method.

There is not so easy to make a right decision about selection of expensive technique (forklifts) which influence company for several years. This decision are usually based on traditional and good experience. Authors of this paper did a support for making right decision job by using selected criteria and evaluate them.

Several criteria have been considered that are of interest to the logistics company, namely 5 (lift capacity, battery capacity, lift height, load speed, and price). The choice is made between four forklift trucks of different manufacturers who have not been appointed for legal reasons. Based on the TOPSIS method, it was decided that the forklift truck 2 the best possible alternative, after that, forklift 4, than forklift 3 and as the worst possible alternative, forklift truck 1 . The TOPSIS method shown in this paper proved to be very useful when making a decision in investing and this is also encouraged by other authors for the same or similar endeavors to find optimal solution.

\section{References}

Bottani, E.; Rizzi, A. 2006. A fuzzy TOPSIS methodology to support outsourcing of logistics services, Supply Chain Management: An International Journal 11(4): 294-308.

Chamodrakas, I.; Leftheriotis, I.; Martakos, D. 2011. In-depth analysis and simulation study of an innovative fuzzy approach for ranking alternatives in multiple attribute decision making problems based on TOPSIS, Applied Soft Computing 11: 900-907.

Chen, C.T.; Lin, C.T.; Huang, S.F. 2006. A fuzzy approach for supplier evaluation and selection in supply chain management, International Journal of Production Economics 102: 289-301.

Chu, T.C.; Lin, Y. C. 2009. An interval arithmetic based fuzzy TOPSIS model, Expert Systems with Applications 36: 10870-10876.

Dimitrijević, B. 2017. Multiatribute decision-making applications in traffic and transport [In Serbian: Višeatributivno odlučivanje - primene u saobraćaju i transportu]. First edition. Faculty of Transport and Traffic Engineering. Serbia. $236 \mathrm{p}$.

Hwang, C. L.; Yoon, K. 1981. Multiple Attribute Decision Making: Methods and Applications, New York: SpringerVerlag. 
Hwang, C.L.; Lai, Y.J.; Liu, T.Y. 1993. A new approach for multiple objective decision making, Computers and Operational Research 20: 889-899.

Kampf, R.; Průša, P.; Savage, C. 2011. Systematic location of the public logistic centers in Czech Republic, Transport 26(4): 425-432.

Sabadka, D.; Molnar, V.; Fedorko, G. 2017. The use of lean manufacturing techniques - SMED analysis to optimization of the production process, Advances in Science and Technology Research Journal 11(3): 187-195.
Shih, H.S. 2008. Incremental analysis for MCDM with an application to group TOPSIS, European Journal of Operational Research 186: 720-734.

Yong, D. 2006. Plant location selection based on fuzzy TOPSIS, International Journal of Advanced Manufacturing Technology 28: 839-844.

Yoon, K. 1987. A reconciliation among discrete compromise situations, Journal of Operational Research Society 38: 277-286.

\section{ijtte ${ }^{398}$}

